\title{
A new species of Micropholcomma (Araneae: Araneoidea: Micropholcommatidae) from Western Australia
}

\author{
Michael G. Rix ${ }^{1,2}$ \\ 'School of Animal Biology M092, The University of Western Australia, \\ 35 Stirling Highway, Crawley, Perth, Western Australia 6009, Australia \\ Department of Terrestrial Zoology, Western Australian Museum, Locked Bag 49, \\ Welshpool D.C., Perth, Western Australia 6986, Australia
}

\begin{abstract}
A new species of Micropholcomma Crosby and Bishop, M. limati, is described from the south coast of south-western Western Australia. Micropholcomma limaei is the first species of Micropholcommatidae to be described from Western Australia, and most closely resembles M. turbans Hickman from Tasmania.
\end{abstract}

\section{INTRODUCTION}

The Micropholcommatidae are a family of small to minute araneoid spiders, known from Australia, New Zealand, New Caledonia, Papua New Guinea, Chile and Brazil (Rix et al. 2008). The nominate genus, Micropholcomma, was first described by Crosby and Bishop (1927), and six species have since been described from Victoria and Tasmania: M. bryophilum (Butler 1932), $M$. caeligenum Crosby and Bishop 1927, M. longissimum (Butler 1932), M. mirum Hickman 1944, M. parmatum Hickman 1944 and M. turbans Hickman 1981 (see Platnick 2008). Despite the small number of described species, the genus Micropholcomma is widespread and quite diverse in both eastern and south-western Australia (see Forster 1959; Main 1974), where species live within the moss and leaf litter of forested habitats. All are tiny, short-legged spiders (usually less than one millimetre in body length), often with heavily sclerotised abdomens and reduced female pedipalps.

Micropholcomma linnaei sp. nov. - the first species of Micropholcomma to be described from Western Australia - is named in honour of Carolus Linnaeus on the $250^{\text {th }}$ anniversary of the publication of Systema Naturae.

\section{MATERIAL AND METHODS}

The specimens examined as part of this study are lodged at the Western Australian Museum, Perth (WAM), the Field Museum, Chicago (FMC) and the American Museum of Natural History, New York (AMNH). All specimens were described and illustrated in $75 \%$ ethyl alcohol. Digital photographs were taken through a Leica MZ16 binocular microscope (Wetzlar, Germany) and an Olympus BH-2 compound microscope (Tokyo, Japan) using a Q-Imaging Micropublisher 5.0 RTV mounted camera (Burnaby, Canada) with Auto-
Montage Pro imaging software by Syncroscopy (http://www.syncroscopy.com/syncroscopy/ am.asp, verified April 2008). Female epigynes were dissected and cleared in a gently-heated solution of $10 \%$ potassium hydroxide.

All measurements are in millimetres, and locality coordinates marked with an asterisk $\left({ }^{*}\right)$ were estimated using Google ${ }^{\mathrm{N}}$ Earth. The following abbreviations are used throughout the text: ALE, anterior lateral eyes; AME, anterior median eyes; PLE, posterior lateral eyes; PME, posterior median eyes.

\section{SYSTEMATICS}

\section{Family Micropholcommatidae Hickman 1944}

Genus Micropholcomma Crosby and Bishop 1927

Micropholcomma Crosby and Bishop 1927; 152.

Microlinyphens Butler 1932: 103. Synonymised by Hickman 1944: 186.

Plectochetos Butler 1932: 106. Synonymised by Forster 1959: 297.

\section{Type species}

Micropholcomma: Micropholcomma cadigenum Crosby and Bishop 1927, by original designation.

Microlimypheus: Micolinyphens bryophilus Butler 1932, by monotypy.

Plectochetos: Plectochetos longissimus Butler 1932 by monotypy.

Micropholcomma linnaei sp. nov.

Figures 1-11

Material examined

Holotupe

Australia: Western Australia: $d$, Walpole- 
Nornalup National Park, Giant Tingle Area, 8 $\mathrm{km}$ north-east of Walpole, 34 $4^{\circ} 59^{\prime} \mathrm{S}, 116^{\circ} 47^{\prime} \mathrm{E}^{*}, 19$ December 1976, mixed Eucalyptus litter, J. Kethley (WAM T85552).

\section{Paratypes}

Australia: Western Australia: Allotype + , same data as holotype (WAM T85553); 33 ऽ, 51 ㅇ, same data as holotype (WAM T85554); 1 o, 3 ㅇ, same data as holotype (FMC); 5 ๘, 2 , , same data as holotype except Karri and Acacia litter (FMC).

\section{Other material examined}

Australia: Western Australia: Walpole-Nornalup National Park: 1 ô, 1 क, Giant Tingle Tree Area,
345․ $588^{\prime}$ S, $116^{\circ} 47.42^{\prime} \mathrm{E}, 2$ August 2004, TingleAllocasuarina-Karri (Eucalyptus diversicolor) forest, 190 m, leaf and bark litter, Newton, Thayer, Clarke (FMC); 1 ㅇ, Giant Red Tingle Area, 6 km north-east of Coalmine Beach, 34 $59^{\circ} \mathrm{S}, 116^{\circ} 47^{\prime} \mathrm{E}$ 13 December 1976, litter under Red Tingle, J. Kethley (FMC); 4 o, 7 q, same data (FMC); 14 o, 14 , same data except litter at base of Red Tingle (FMC); 1 o, 2 क, same data except litter under Casuarina (FMC); 8 o, 12 q, same data (FMC); 2 ㅇ, Red Tingle turn-off, $5 \mathrm{~km}$ north-east of Coalmine Beach, 345' $\mathrm{S}, 116^{\circ} 47^{\prime} \mathrm{E}$, 5 December 1976, litter at base of log, J. Kethley (FMC); 1 ऽ, 1 q, same data (FMC); 1 o, 1 \%, same data except fungal mat

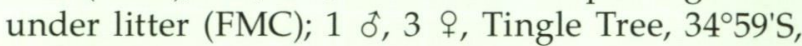
$116^{\circ} 47^{\prime} \mathrm{E}, 18$ June-29 July 1980, litter, S. and J. Peck
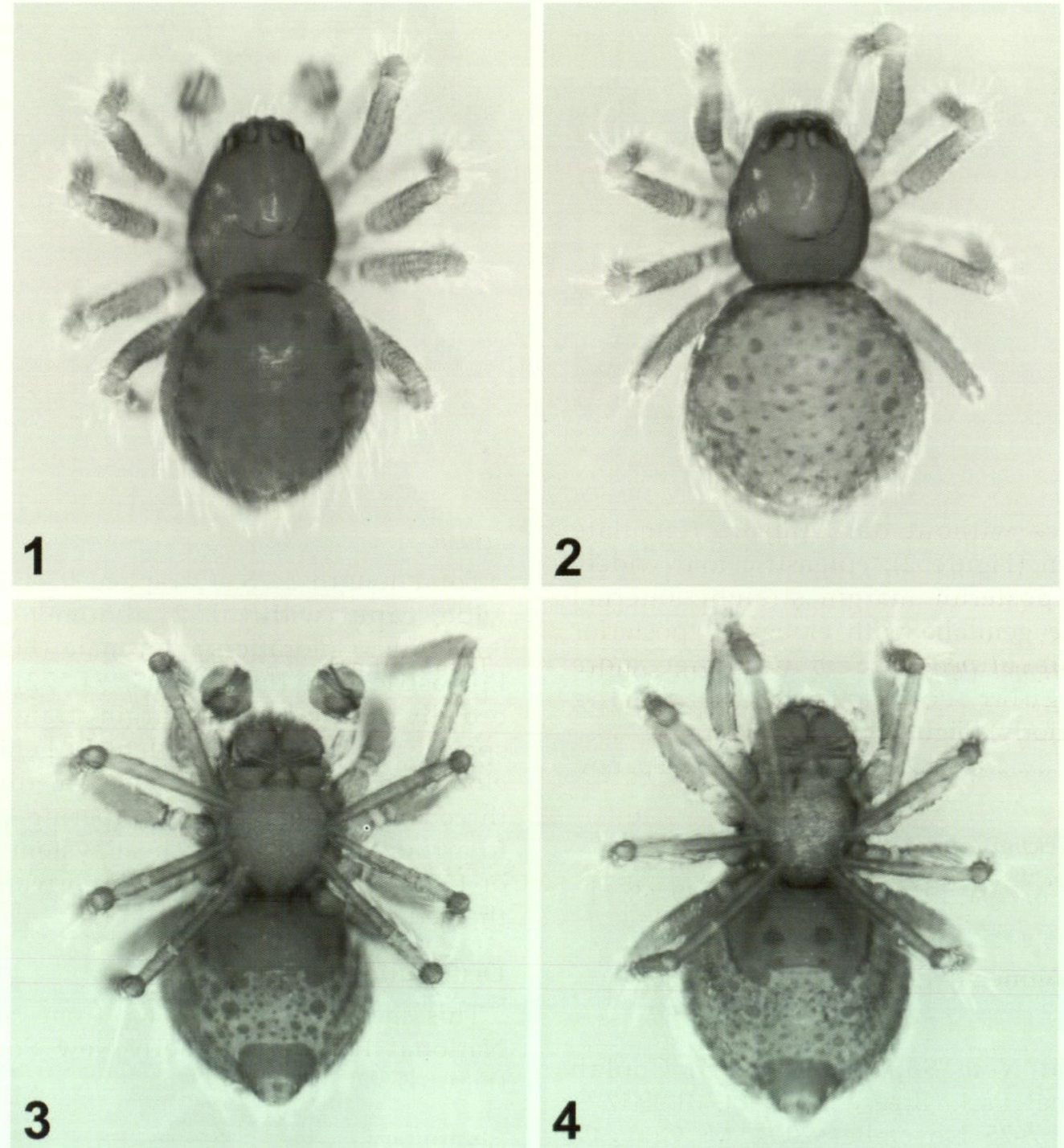

Figures 1-4 Micropholcomma linnaei sp. nov., paratype male and female from Walpole-Nornalup National Park (WAM T85554): 1, male habitus, dorsal view; 2 , female habitus, dorsal view; 3 , male habitus, ventral view; 4 , female habitus, ventral view, showing the distinctive epigyne with visible spermathecae. 


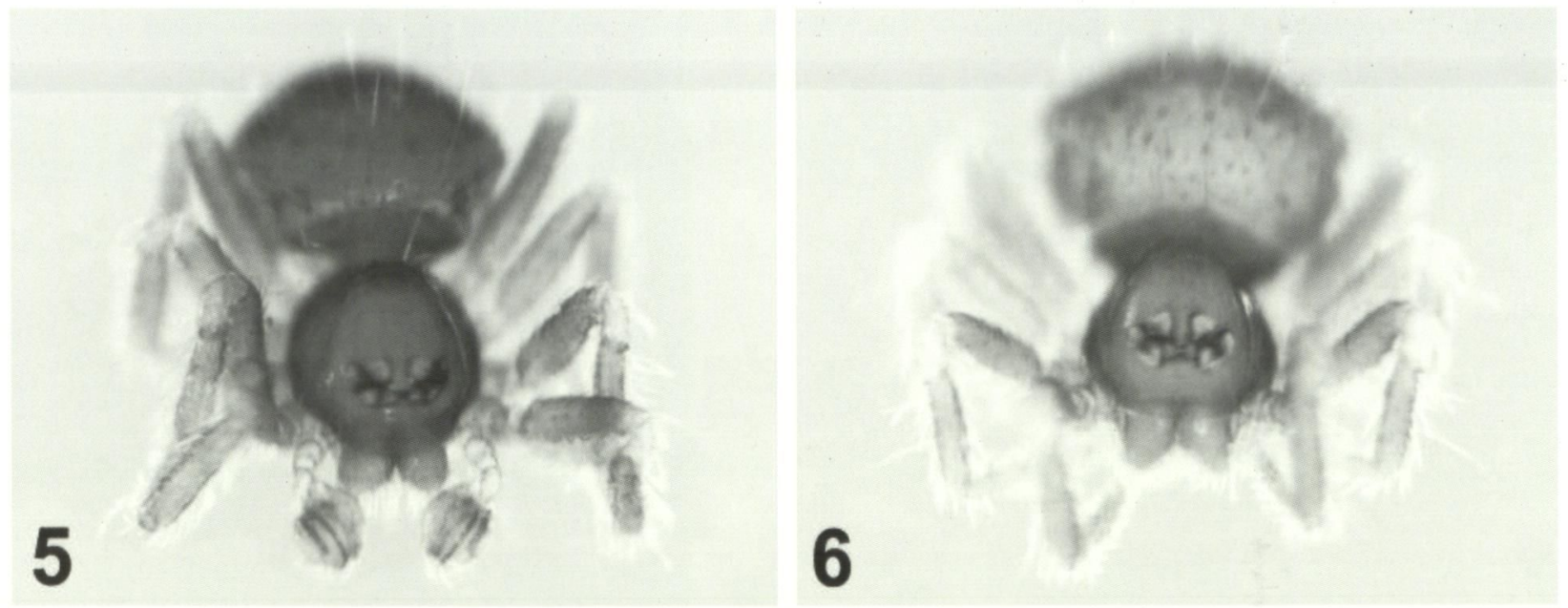

Figures 5-6 Micropholcomma linnaei sp. nov., paratype male and female from Walpole-Nornalup National Park (WAM T85554): 1, male habitus, frontal view; 2 , female habitus, frontal view.

(AMNH); 2 , same data except 4 July 1980, log and Casuarina litter (AMNH); 2 ô, 2 q, Anderson Road, near Valley of the Giants Road, 34'59'29"S, $116^{\circ} 52^{\prime 2} 21 " E, 2$ August 2004, Tingle-AllocasuarinaKarri (Eucalyptus diversicolor) forest, $120 \mathrm{~m}$, leaf and bark litter, Newton, Thayer, et al. (FMC); 2 ऽ, Shedley Drive, $35^{\circ} 00^{\prime} \mathrm{S}, 116^{\circ} 38^{\prime} \mathrm{E}, 22$ June 1980 , fungi and bark litter, S. and J. Peck (WAM T85555); 1 \%, same data (WAM T87/1119-24); 1 oे, 1 \%, same data (AMNH); 5 ㅇ, Collier Road, 345' $59^{\prime} \mathrm{S}, 116^{\circ} 46^{\prime} \mathrm{E}$, 19 June 1980, Tingle base, S. and J. Peck (AMNH); 4 ơ, 1 ㅇ, same data (AMNH).

Mount Frankland National Park: 2 ơ, 2 , Mount Frankland, $29 \mathrm{~km}$ north of Walpole, 34 $49^{\prime} \mathrm{S}$, $116^{\circ} 47^{\prime} \mathrm{E}, 15$ December 1976, unburned litter below switch-back in Forestry Road, J. Kethley (FMC); 10 के, 7\%, same data (FMC); 2 के, 4 \%, Mount Frankland, $28 \mathrm{~km}$ north-east of Walpole, $34^{\circ} 49^{\prime} \mathrm{S}$, $116^{\circ} 47^{\prime}$ E, 17 December 1976, litter under Red Tingle, J. Kethley (FMC).

Warren National Park: 8 o, 17 q, 16 km southwest of Pemberton, $34^{\circ} 30^{\prime} \mathrm{S}, 115^{\circ} 56^{\prime} \mathrm{E}, 12$ December 1976, Karri litter, J. Kethley (FMC); 6 o, 16 \&, same data (FMC); 6 \%, same data except Allocasuarina decussata litter (FMC).

Other localities: 1 \&, near Limeburners Road, adjacent to Torndirrup National Park, $35^{\circ} 05^{\prime} 27^{\prime \prime}$, 117 54 '40"E, 14 March 2008, Karri forest, sifting elevated leaf litter in deep gully, M. Rix, M. Harvey (WAM T88757).

\section{Diagnosis}

Males can be distinguished from all other described congeners except $M$. turbans and $M$. longissimum by the long embolus, which extends around the pedipalpal bulb one-and-a-half times (rather than a short embolus which encircles the bulb once; see Hickman 1944, fig. 11) (Figures
9-10); from $M$. turbans by the shorter embolus with coils that are separated rather than tightly coiled (Figures 9-10); and from M. longissimum by the absence of a very long, tightly coiled (i.e. 'super-coiled') embolus (see Forster 1959, fig. 67; Forster and Platnick 1984, fig. 369). Females can be distinguished from all other described congeners except M. bryophilum and M. longissimum by the presence of a small, four-segmented pedipalp (rather than a vestigial nubbin on the maxilla; see Hickman 1944, fig. 29); from M. bryophilum by the absence of a dorsal scute (Figure 2); and from M. longissimum by the shorter receptacula, with the spermathecae situated closer to the epigastric furrow than to the pedicel (Figures 4, 7-8; see also Forster 1959, fig. 66).

\section{Description}

\section{Holotype male}

Total length 0.80 . Carapace 0.36 long, 0.30 wide. Abdomen 0.58 long, 0.43 wide. Leg I femur 0.23 long. Colour: carapace, chelicerae, sternum tan-brown; eyes pearly-white with black margins; legs tan-brown, patellae lighter; dorsal scute, anterior sclerite, spinneret sclerite, lateral sclerites and setal sclerotic plates of abdomen tan-brown, rest of abdomen cream, with dorsal sigillae darker tan-brown. Carapace: in lateral view rhomboidal, with posterior pars cephalica rising vertically at angle to steeply-rising pars thoracica; setae present on dorsal pars cephalica and around eyes and clypeus, with four longer, porrect, anteriorly-curved and length-descending setae present along medial pars cephalica (in posterior-anterior formation 2, 1, 1). Eyes: ALE, PME, PLE in two separated triads; AME smallest, separating ALE. Sternum: slightly longer than wide, posteriorly truncate (with coxae of leg IV 

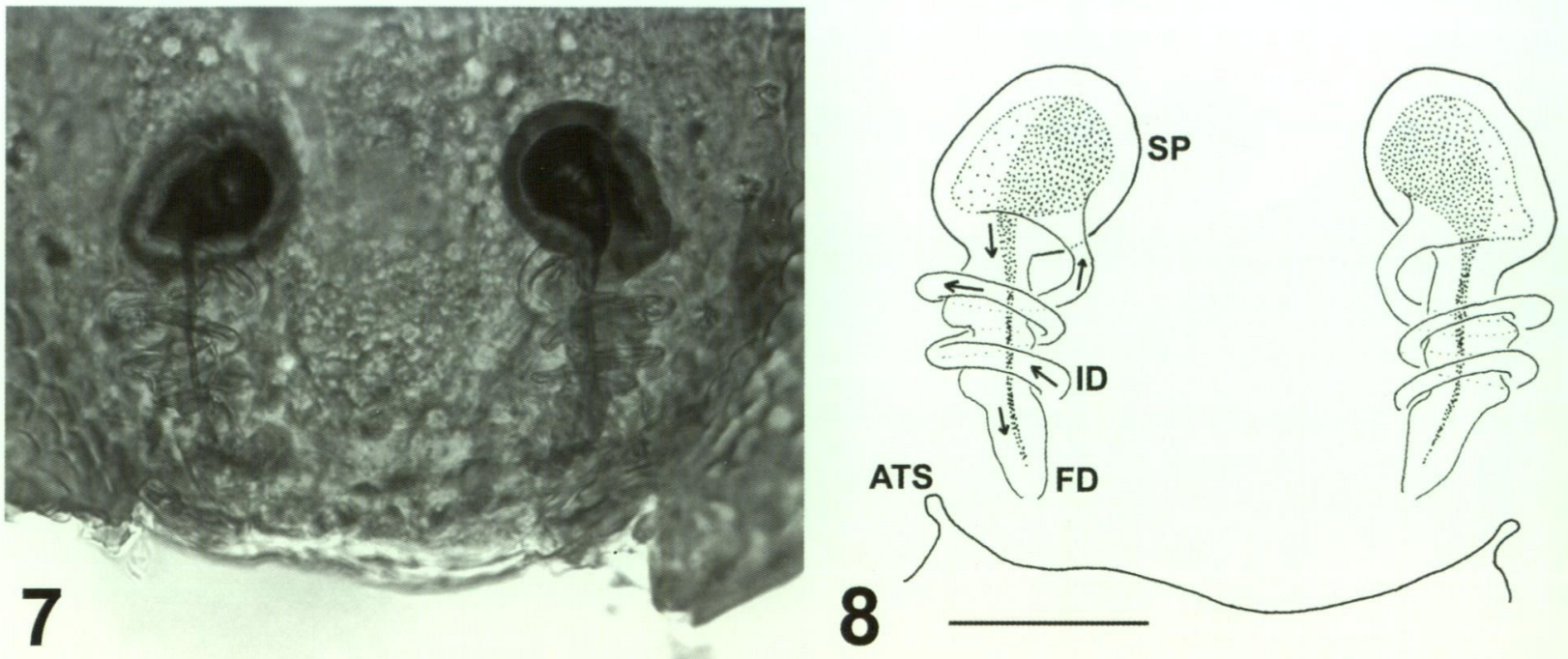

Figures 7-8 Micropholcomma linnaei sp. nov., paratype female from Walpole-Nornalup National Park (WAM T85554): 7, photograph of cleared receptacula, dorsal view; 8, receptacula, dorsal view, showing spermathecae and ducts. ATS, anterior tracheal spiracle; FD, fertilisation duct; ID, insemination duct; SP, spermatheca. Scale bar $=0.048 \mathrm{~mm}(48 \mu \mathrm{m})$.

widely separated), fused to carapace between coxae of legs and around pedicel. Labium: triangular, wider than long, fused to sternum. Maxillae: directed across labium; serrula a single row of teeth. Chelicerae: rectangular, distally divergent, bulging slightly anteriorly; promargin with pair of setae adjacent to base of fang, one peg-tooth-like seta and one broad, triangular tooth; retromargin with two smaller teeth. Abdomen: oval, overhanging posterior margin of carapace, covered in posteriorly-curved setae each projecting from small sclerotic plate; dorsal scute large, covering most of dorsal surface of abdomen, with marginal ring of 18 circular sigillae and several smaller sigillae; anterior sclerite surrounding pedicel and covering entire epigastric region, extending laterally behind epigastric furrow; spinneret sclerite encircling the spinnerets, longest ventrally; abdomen also with numerous small sclerites in rows laterally and ventrally; posterior tracheal spiracle situated slightly anterior to spinnerets. Spinnerets: six present, posterior to colulus. Legs: longest to shortest 4, 1, 2, 3; relatively short (leg I femurcarapace ratio 0.64 ), covered in setae; patellae each with single distal bristle-like seta and tibiae each with two bristle-like setae and three trichobothria; trichobothria absent on metatarsi. Pedipalp: patella with broad, distal, retrolateral apophysis terminating in spinous process; cymbium circular, cup-shaped, with marginal curved setae; tegulum with curved, evaginated tegular ridge situated within internal coil of embolus; embolus long, coiling around bulb one-and-a-half times.

\section{Allotype Female}

Total length 0.94. Carapace 0.37 long, 0.31 wide. Abdomen 0.70 long, 0.50 wide. Leg I femur 0.29 long. Colour: carapace, chelicerae, sternum tanbrown; eyes pearly-white with black margins; legs tan-brown, patellae lighter; anterior sclerite, spinneret sclerite, lateral sclerites, sigillae and setal sclerotic plates of abdomen tan-brown, rest of abdomen cream. Carapace: with steeply-rising pars thoracica and posterior pars cephalica; setae present on dorsal pars cephalica and around eyes and clypeus, with four longer, porrect, anteriorlycurved and length-descending setae present along medial pars cephalica (in posterior-anterior formation 2, 1, 1). Eyes: ALE, PME, PLE in two separated triads; AME smallest, separating ALE. Sternum: slightly longer than wide, posteriorly truncate (with coxae of leg IV widely separated), fused to carapace between coxae of the legs and around pedicel. Labium: triangular, wider than long, fused to sternum. Maxillae: directed across labium; serrula a single row of teeth. Chelicerae: rectangular, distally divergent; promargin with pair of setae adjacent to base of fang, one peg-tooth-like seta and one broad, triangular tooth; retromargin with two smaller teeth. Abdomen: oval, overhanging posterior margin of carapace, covered in posteriorly-curved setae each projecting from a small sclerotic plate; dorsal surface with marginal ring of 18 circular sigillae and several smaller sigillae; anterior sclerite surrounding pedicel and covering entire epigastric region, extending laterally behind epigastric furrow; spinneret sclerite encircling the spinnerets, longest ventrally; abdomen also 


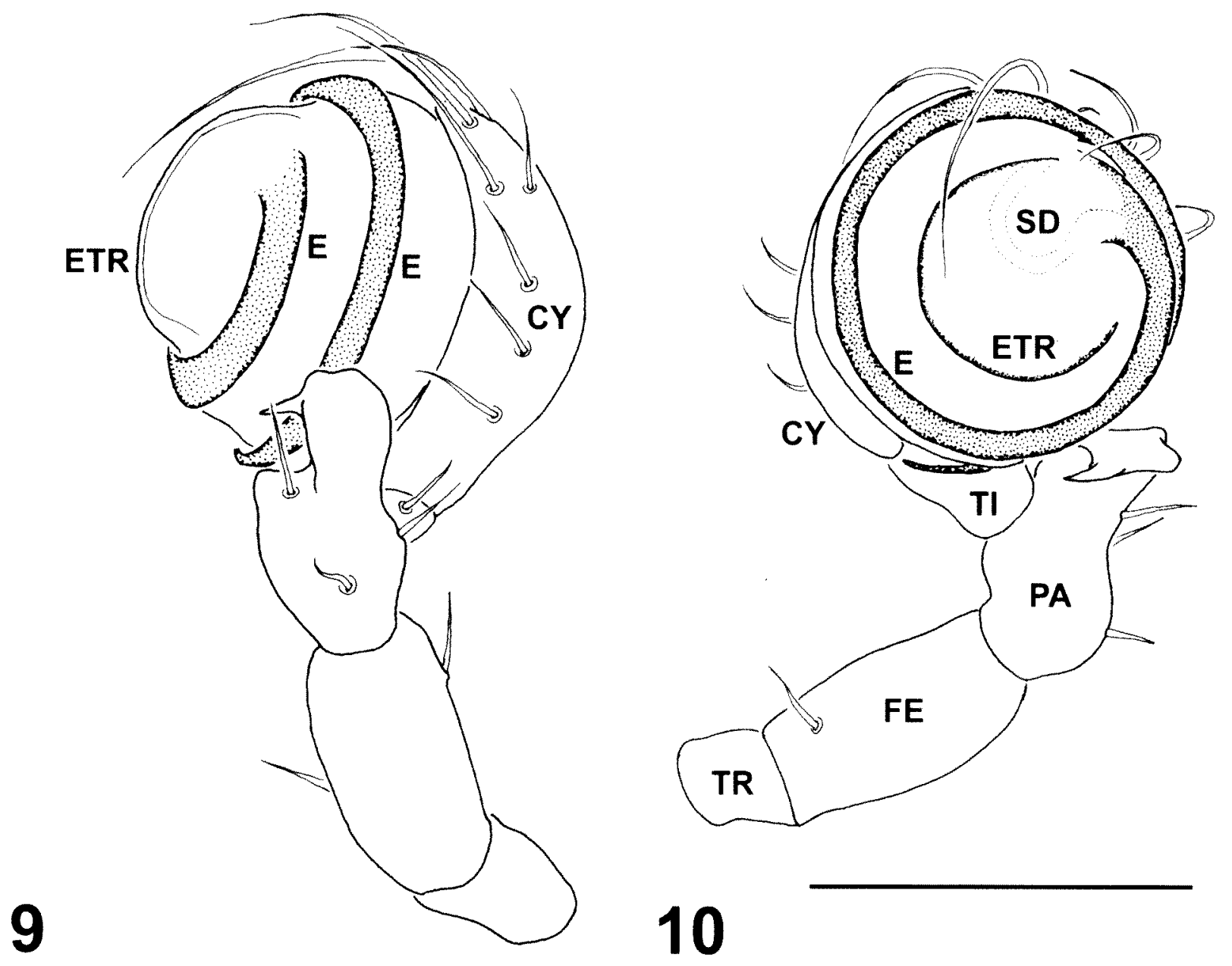

Figures 9-10 Micropholcomma linnaei sp. nov, paratype male from Walpole-Nornalup National Park (WAM T85554): 9. pedipalp, retrolateral view; 10, pedipalp, ventral view. CY, cymbium; E, embolus; ETR, evaginated tegular ridge; FE, femur; PA, patella; SD; sperm duct; Tl, tibia; TR, trochanter. Scale bar $=0.11 \mathrm{~mm}(110 \mu \mathrm{m})$.

with numerous small sclerites in rows laterally and ventrally; posterior tracheal spiracle situated slightly anterior to spinnerets. Spinnerets: six present, posterior to colulus. Legs: longest to shortest 4, 1, 2, 3; relatively short (leg I femurcarapace ratio 0.78 ), covered in setae; patellae each with single, distal bristle-like seta and tibiae each with two bristle-like setae and three trichobothria: trichobothria absent on metatarsi. Pedipalp: reduced in size, four-segmented, with trochanter, femur, patella and fused tibia-tarsus. Epigyne: externally distinctive, with receptacula clearly visible through anterior sclerite; intromittent pores transversely-oval, situated slightly anterior to epigastric furrow and anterior tracheal spiracles; insemination ducts long, coiled, encircling fertilisation ducts two times, leading into globular spermathecae; fertilisation ducts long, straight, posteriorly-directed.

\section{Distribution and habitat}

Micropholcomma limmati is currently known from Walpole-Nornalup, Mount Frankland and Warren National Parks, and from near Torndirrup National Park on the far south coast of south-western Western Australia (Figure 11). The species is probably restricted to the tall, wet Karri and Tingle (Eucalyptus spp.) forests which extend between Margaret River and Albany, and specimens have been collected from leaf litter and fallen bark.

\section{Etymology}

The specific epithet is a patronym in honour of Carolus Linnaeus (1707-1778), the founder of binomial nomenclature and author of Systemo Naturac.

\section{ACKNOWLEDGEMENTS}

This research contributed to a Doctor of Philosophy (Ph.D.) degree at the University of Western Australia, and was funded by the Australian Biological Resources Study (ABRS) Ph.D. Research Scholarship (2006-2009) and the School of Animal Biology at the University 


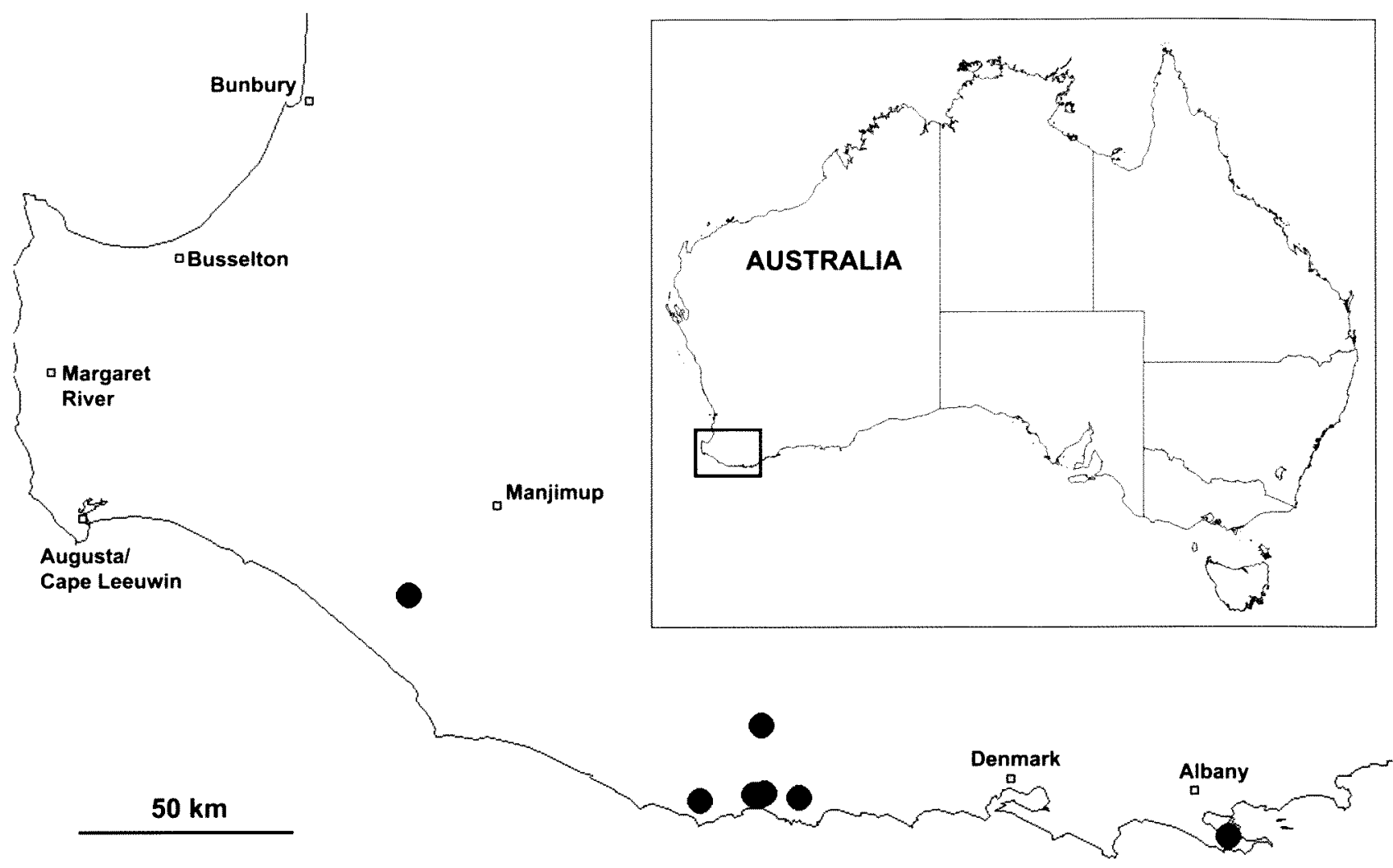

Figure 11 Map of south-western Western Australia, showing the recorded distribution of Micropholcomma linnaei sp. nov. ()

of Western Australia. I would like to thank Mark Harvey (Western Australian Museum) and Dale Roberts (The University of Western Australia) for their supervision and guidance. I am also extremely grateful to Petra Sierwald and James Boone (Field Museum, Chicago) and Norman Platnick and Louis Sorkin (American Museum of Natural History, New York) for the loan of important material, and to Petra Sierwald for authorising the donation of the type specimens to the Western Australian Museum. Norman Platnick and Volker Framenau (Western Australian Museum) provided helpful comments on an earlier draft of the manuscript.

\section{REFERENCES}

Butler, L.S.G. (1932). Studies in Australian spiders, No. 2. Proceedings of the Royal Society of Victoria 44: 103-117.

Crosby, C.R. and Bishop, S.C. (1927). New species of Erigoneae and Theridiidae. Journal of the New York Entomological Society 35: 147-154.

Forster, R.R. (1959). The spiders of the family Symphytognathidae. Transactions of the Royal Society of New Zealand 86: 269-329.
Hickman, V.V. (1944). On some new Australian Apneumonomorphae with notes on their respiratory system. Papers and Proceedings of the Royal Society of Tasmania 1944: 179-195.

Hickman, V.V. (1981). New Tasmanian spiders of the families Archaeidae, Cycloctenidae, Amaurobiidae and Micropholcommatidae. Papers and Proceedings of the Royal Society of Tasmania 115: 47-68.

Main, B.Y. (1974). Occurrence of the lungless spider Micropholcomma Crosby and Bishop in south-west Western Australia (Araneae: Symphytognathidae). Journal of the Australian Entomological Society 13: 79.

Platnick, N.I. (2008). The World Spider Catalog, Version 8.5. American Museum of Natural History, New York, online at: http://research.amnh.org/entomology/ spiders/catalog/INTRO1.html (accessed 21 April 2008).

Rix, M.G., Harvey, M.S, and Roberts, J.D. (2008). Molecular phylogenetics of the spider family Micropholcommatidae (Ararchnida: Araneae) using nuclear rRNA genes (18S and 28S). Molecular Phylogenetics and Evolution 46: 1031-1048.

Manuscript received 27 March 2008; accepted 6 May 2008. 